Volume 11 Number 3, July-September 2017: pp. 246- 265 . Copyright (c) 2017 FIAT JUSTISIA. Faculty of Law, Lampung University, Bandarlampung, Lampung, Indonesia. ISSN: 1978-5186 | e-ISSN: 2477-6238.

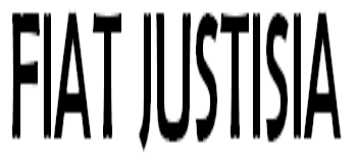

Fiat Justisia is licensed under a Creative Commons Attribution 4.0 International License, which permits unrestricted use, distribution, and reproduction in any medium, provided the oriainal work is properly cited.

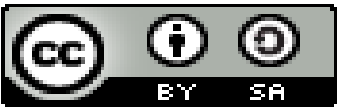

\title{
The Identity Politics of the Minority in Knitting the Constitutionality (The Legal review of Sunda Wiwitan Community of Cigugur, Kuningan, West Java)
}

\author{
Sarip \\ University of Muhammadiyah Cirebon \\ sarip_anisa@yahoo.co.id
}

\begin{abstract}
The Identity Politics of Sunda Wiwitan community, which nowadays is rated as a form of self-preservation to meet the economic needs of families, has been considered to get restraints from the state. The economic needs make the identity politics as a means to save oneself. The Identification card, which is known as KTP and in which there is a religion column, has created discrimination of the identity for the Sunda Wiwitan Community $(K S W)$. The KSW still runs the obedience to the teachings of the ancestors but to save the economy, the status of the religion is willingly written to be recognized as other religions by the state. There is no other way to save the economic life for the sake of the family survival than to fill in the religion column with the state-recognized religions. The situation is certainly influential for the KSW against other identities such as marriage and education cards. The discussion uses the result that comes from the interviews and some literature. Then the result becomes something ideal for $K S W$ to save themselves in the economic field by changing the identity on the $I D$ card. It is the way from KSW in passing the identity politics to meet the economic needs while the other side becomes the weakness of the Indonesian national law that does not provide any space for $K S W$ in order to have equal opportunity as the Indonesian citizen.
\end{abstract}

Keywords: The Identity Politics, KSW, Constitutionality. 


\section{A. Introduction}

The Sunda Wiwitan Community (KSW) continues to fight for the identity politics to gain constitutional rights. ${ }^{1}$ Identity politics was intensified after Abdurahman Wahid's visit to Paseban Tri Panca Tunggal Building in 1999. ${ }^{2}$ Judging from the time span, new social scientists are drawn to the issue identity politics in the 1970s, began in the United States, when facing minority, gender, feminism, race, ethnicity, and issues other social groups that feel marginalized, feel persecuted. The visit was a motivation in facing the pressures in the majority field.

Further coverage of the identity politics of the Sunda Wiwitan Community (KSW) extends to religious issues, beliefs, and as citizens of Indonesia who are not entitled to constitutional rights. ${ }^{3}$

The identity of the KSW does not include the KSW religion on the identity card of the Identity Card (KTP). KSW has difficulty finding employment and promotion for Civil Servants (PNS) in improving economic welfare. Identity politics as a form to facilitate the acquisition of constitutional rights that are felt less fulfilled by the state. Issues about identity as citizens of Indonesia became central in the political discourse of KSW identity. The identity politics of KSW, a problem that is not easily explained especially about religion. Many statements claim that the KSW is a non-believer, an atheist. ${ }^{4}$ Arriving at the film culture, producing a film titled "KAFIR" played by Sujewo Tejo, a blow to KSW, the teachings of

\footnotetext{
${ }^{1}$ Constitutional right referred to in this article are basic rights as citizens as contained in the 1945 Constitution The Constitution has been known since the Age of Ancient Greece, in Greek society said that Politea interpreted as constitution, while nomoi interpreted as legislation. So that the position of the constitution is higher than the law. Kusnardi and Harmaily Ibrahim, Hukum Tata Negara Indonesia (translate: Indonesia Constitutional Law), Jakarta: University of Indonesia, (2000), p. 62. See also Titik Triwulan Tutik, Pokok-Pokok Hukum Tata Negara (translate: Principles of Constitutional Law), Jakarta: Perstasi Indonesia, (2006), p. 43. Look et Djokosutono, Hukum Tata Negara/Constitutional Law, lectures compiled by Harun Alrasid in 1959, Jakarta: Ghalia Indonesia, 1982, pp. 47-48. Look et Dahlan Thaib et all, Teori Hukum dan Konstitusi/Theory and Law of the Constitution,, Jakarta: Raja Grafindo Persada, (2004), p.8

${ }^{2}$ The visit Wahid basically not to Tri Panca Tunggal Paseban Building a Community had Sunda Wiwitan building located in the Village Cigugur, Cigugur subdistrict, Kuningan regency, West Java province. But to the invitation of Ulama in Sagara Hiyang, Description Dewi Kanti and Oki Satrio, at the Discussion About KSW Cigugur in Paseban October 22, (2012).

3 Ahmad Syafii Maarif, Politik Identitas dan Masa Depan Pluralisme Indonesia/Political Identity and Future of Indonesian Pluralism, Jakarta: Foundation of the Century of Democracy, (2012), p.3

${ }^{4}$ This statement is said by one SMA Mardi Waluya Cibinong, last week during a speech in pemiihan King and Queen at Art Studio Cigugur, November 10, 2012. Its stated "Cigugur coexist with different people of different religions, although still nothing atheist " .
} 
ancestors have been misunderstood. Not drink the sweat of the character to gain blessings, but "eat and drink from your sweat."

KSW retains the Sundanese ancestral tradition, in the areas of belief, tradition, and art. as Religion, KSW knows the local teachings of belief in God Almighty. ${ }^{5}$ The KSW tradition preserves traditional ceremonies such as Seren Taun and Satu Sura events; the arts include Sundanese gamelan, Kidung, children's games, Buyung Dance, Numbuk Padi, and Angkung Buncis. ${ }^{6}$ Religion, tradition, and art, as constitutional rights contained in the 1945 Constitution Article 18-B Paragraph (2) which is as follows:

The State recognizes and respects the unity of indigenous and tribal peoples along with their traditional rights as long as they are alive and by the development of society and the principle of the Unitary State of the Republic of Indonesia regulated by law ".

The question then is whether the demand for KSW's identity on religion in KTP will build the economy to be better? To answer the main questions, it must be answered the first question derived (1) what the status of KSW marriage in the eyes of the law is? (2) What is the right to fulfill the education before getting a job in handling it?

\section{B. Methodology}

The methodology used is done by finding information through the interviews with some of KSW civil servants and private employees, through interviews are expected to find a common thread and get a bright spot about the identity being fought. The type of research itself uses descriptive qualitative research, conducted by way of describing field facts. Then conduct normative legal analysis through formal legal rules that are considered to discriminate and support the KSW in knitting constitutional rights. From the description of the existence of being found trying to draw conclusions that match the formulation of the problems that have been presented.

\footnotetext{
5 The doctrine local KSW a divine teachings learned from nature, as the book of life in everyday life.

${ }^{6}$ It is proved that, the more advanced of science and knowledge possessed by a particular community will become more frequent as well the demands of human rights as a human and constitutional rights as citizens, want recognition firm and does not float, as it is said by Darja in Taman Paseban Tri Panca Tunggal Cigugur, Brass, November 7, 2012. so also is said by Suhari stating we were experiencing difficulties to get a job and education due to the assumption that we're not a religious, interview Cipager Wetan, Cigugur, Brass, November 3, 2012.
} 


\section{Analysis and Discussion}

\section{Political Identity: Theory Framework and Praxis Form For Minorities in Knitting Constitutional Rights}

Political identity does not sound resonate among the people, moreover if it is related to the identity which is used to knit the constitutionality. LA. Kauffman first explained the identity politics by tracing the origin of the anti-violent student movement known as SNCC (the Student Nonviolent Coordinating Committee), an organization of the civil rights movement in the United States in the early 1960s. ${ }^{7}$ The Political identity of L.A. Kauffman is directly proportional to a social group that feels discriminated against by the state. The theoretician of identity politics argues that the practice of extortion builds the consciousness of an extortionist class, a society that feels marginalized. ${ }^{8}$ The form of identity politics is sticking out to the limits of sacrificing identity for the economy. The Political Identity of the KSW is in line with the movements of Martin Luther King and Catholic bishops in America, driven by the argument of social justice, not for religious reasons. $^{9}$

The KSW perspective on identity politics is not much different from Martin Luther King's movement. KSW experienced unfair treatment, and they also want equality as citizens, critical law scholars in Indonesia have not touched identity politics of KSW. ${ }^{10}$ Learning more about the nature of identity politics in viewing the identity of the KSW as a minority in the knit of constitutional rights. Before 1999, it never conducted the Seren Taun ceremony, ${ }^{11}$ after the arrival of Abdurahman Wahid, the new KSW dared to re-implement it, which has been stuck for fifteen years.

The identity politics of KSW is supported by Abdurahman Wahid in the effort to maintain the pluralism of the Unitary State of the Republic of Indonesia (NKRI). For KSW the support meant as the way to win the identity of ID card politics that has been running since 21 September $1964 .{ }^{12}$ It was the time when the KSW is required to embrace one of the recognized

\footnotetext{
${ }^{7}$ Ahmad Syafei Maarif, Identity Politics and the Future of Pluralism We, the Foundation Ab ad Democray, Jakarta, (2012), p. 4. Ahmad Syafii Maarif, Islam in the Indonesian Framework of Keindonesiaan and Kema nusiaan: A History Reflection, Bandung and Jakarta: MizanMaarif Institute, (2009), pp. 125-127.

${ }^{8}$ LA. Kaufffman, "The Anti-Politics of Identity", Socialist Review, 20 (1), pp. 67-80.

${ }^{9}$ Gutmann in Ahmad Syafei Maarif, Ibid., p 5.

${ }^{10}$ Ahmad Mahmudi, Knowledge No Ivory Tower: Studies in Research Should Favor And N Studies The Impartial , Cigugur October 22, 2012 in the National Symposium event.

${ }^{11}$ Seren Taun an annual ceremony which is a form of thanksgiving to nature that has given life to human beings and since 1981 has banned later in 1999 revived.

${ }^{12}$ Dewi Kanti , Dynamics of Spiritual Ancestors Preserving Sunda Wiwitan, Cigugur, October 16, (2012), p. 2.
} 
religions of the country such as Hinduism, Buddhism, Catholicism, Protestantism, and Islam. The political movement of the identity of Djatikusumah in 1981 restated to the KSW, to preserve the identity of the ancestors of the KSW, previously incorporated in the Catholic religion.

Secretly members of KSW who come from various regions such as Kuningan, Garut, Tasik, Cirebon, Indramayu, and Kanekes rejoined and ignored the identity of ID cards. The walls of religion and the state were less supportive after the reform of the KSW tried to escape from the confines of discrimination and tried to knit the rights of constitutionality. The anxiety of society lives side by side; a million unknown mysteries remain in the identity politics. ${ }^{13}$ Mudiono says the transition from village to kelurahan as "the change of status was a desire of the government imposed." The mystery had not been revealed more due to the geographical location of Cigugur which was far from the center of Kuningan City, made as kelurahan in 1986. In 1986 was still regarded as a simple area, forced into the village said by Mudiono as: ${ }^{14}$

"In the event of status from village to kelurahan, there has been the taking of village assets including Balong Dalam, which is a source of water for fishery and agricultural purposes. I rejected this incident transitional status from village to village because Cigugur does not deserve to sed an in the village at the time. However, the effort failed because of the increasingly heated political situation. I think Cigugur's transition from village to kelurahan is more due to political content only. For example, People's fiefs are priced at 50,000, - per brick /14M ${ }^{2}$, then replaced by other lands that have varying prices, i.e., 5,000, 7,500, and 10,000. However, it is now unknown where the land is until now. So the rejection I did not work, even I got an intro- dation from the Koramil related to the rejection I did, but because of the rest of the community, I was afraid that eventually, the business would fail."

In 1986, the status of Cigugur village was known as an urban area. ${ }^{15}$ As a result, all KSW custom traditions gets strict supervision from the

\footnotetext{
${ }^{13}$ The information conveyed by Ms. Uum in his place Cipager Wetan, and a description of the pack Kento who are citizens of the District Cigugur Cipager Cigugur Wetan Village District Brass. In the month of October 6, 2012. A description of Mr. Ono who is a citizen Paleben Cigugur Kuningan district on October 31, 2012. Slamet DKK, "Pemanfaata Ruang Telaga Pada Tradisi Sedekah Bumi Desa Cerme Kidul Kecamatan Cerme Kabupaten Gresik", Jurnal RUAS, 13 (1), (2015), p. 45.

${ }^{14}$ Here the author does not explain the mystery of the saved thousand, because it requires or to be included in a separate discussion later be searched root problem or political forces associated with the transition to the rural districts.

${ }^{15} \mathrm{Mr}$. Ono who is a citizen Paleben this interview was done on his home, Cigugur, Brass, October 29, 2012.
} 
kelurahan including the limitation of the KSW movement in the field of teaching and culture. Issues that developed at the time, no more to oversee the existing KSW in Cigugur. Prove it by the enlarged road between the Paseban Tri Panca Tunggal Building with the Marapat Lima Building, now become the provincial road. Also, the construction of roads now can be passed by four-wheeled vehicles that at once separate Paseban and Park Lememah Paseban. The end of the search for KSW identity politics found the phenomenon of Sunda Wiwitan who teaches "the traits of human beings and the traits of the nation" takes the foundation of the human realm of Sunda.

Paseban Tri Panca Tunggal building located in the Cigugur highway is a real proof of the relic of the phenomenal character named Prince Madrais Sadewa Alisbasya Kusuma Wijayadingingrat which was better known as Madrais. PasebanTri Panca Tunggal building, since 1974 was served as a national cultural heritage building. ${ }^{16}$ It is increasingly missing the identity of the KSW itself. Further search about Paseban Tri Panca Tunggal Building, the author is not yet aware of the politics and law of giving the award. Building Tri Panca Tunggal itself when considered, take the architecture of the era of ancestral beliefs of Indonesia that is shaped "Punden Berundak." Citizenship as a national cultural heritage building is inseparable from the phenomenal figure that teaches "the values of nationality and the values of humanity." A figure who teaches human values and national values in the face of colonialism. Until now, it has been done in descending descent, starting from Madrais (founder), Teja Buana (Son of Madrais), and Djatikusumah (Grandson of Madrais). Madarais lived in 1832-1940 AD. ${ }^{17}$

The Political Identity of Madrais developed the traditional values of the Sundanese teachings, which nowadays that spiritual community is wellknown as KSW. The Political Identity of Madrais as the Sundanese teachings in the early coming or in the ancestors time taught the spiritual tradition of the Sundanese ancestral culture known as "the traits of human beings and the traits of the nation." The spirit of the culture saw the condition of the nation which was full of unfairness and cruelty in the colonialism. ${ }^{18}$ The Madrais reflected the essence of the humanitarian and nationality life from the tradition of the ancestor teachings that always learned from nature and the environment. The marriage culture itself was

\footnotetext{
${ }^{16}$ House Tri Panca Tunggal Paseban monument protected by Ordinance 238/1931 Stbl DIT Directorate of History and Archeology. Jen Culture Dep. Education and culture.

${ }^{17}$ Description Dewi Kanti , Dynamics of Spiritual Ancestors Preserving Sunda Wiwitan, Cigugur, in October 2012. In NYC Participant , p. 2.

18 C.F Strong, The Constitutions of Modern Politics The Study of the History and Establishment of the Constitutions of the World, SPA Teamwork, Bandung: Nuansa and Nusamedia,: (2004), p. 8.
} 
approved by Hindia Belanda since 1926. Identity politics Madrais existed before the Congress of the Youth Pledge October 28, 1928, and August 17, 1945. Indonesia's Independence Madrais formulate the political identity for the cultural movement with the awareness of nationality values and humanity values. Madrais has succeeded in instilling a national identity politics wrapped up by cultural traditions to its students. Madrais' identity politics about the values of nationality and humanity finally caught by the Dutch colonial government. As a result of his actions Madrais, in 1901-1908 arrested and exiled to exile to Tanah Merah (Maluku), on the charge that Madrais has established a new religion. This was done by the Dutch colonial government to restrict the movement of Madrais teachings to instill the values of nationality and humanitarian values. Dutch colonial efforts continued to restrict the movement of Madrais, labeling the Religion of Javanese Sunda (ADS). According to Dewi Kanti associated with ADS, that his great-grandfather once said: ${ }^{19}$

That what he teaches is not to increase the number of existing religions, but there must be a religious understanding that needs to be re-reflected into self-awareness as human beings, and personal awareness as a nation.

The label given by the Dutch colonials made Madrais legitimized by Dutch colonial law and politics and influenced the clerics that Madrais had established a new religion. ${ }^{20}$ The label gave by the Dutch colonial government, Madrais finally endured the legal and political stagnation played by Dutch colonialists and not a few clerics who claimed that Madrais had apostatized, disbelieved, and denied the teachings of religion. ${ }^{21}$ On the one hand it was an obstacle for Madrais to inculcate human values and national values and on the other hand, a colonial was successful in applying the vide et impera politics to combat movements that defy the law - Dutch colonial law. The label against the teachings of the Madrais, given to the spiritual vocations, often referred to them as ADS. The ADS label was acknowledged by Dewi Kanti, Gumirat Barna Alam, and the adherents of

\footnotetext{
${ }^{19}$ Dewi Kanti S. Dynamics Preserving Ancestral Spirituality Sunda Wiwitan, presented in the discussion Training Participatory Action Reasech (PAR), in room Sri Manganti Paseban House Tri Panca Tunggal, Cigugur, October, (2012).

${ }^{20}$ In this way, many carried out by the Dutch colonial government in an attempt to burn down the local teachings had been believed by the people who live in Indonesia.

${ }^{21}$ The word infidel, apostate and heretical, the teachings of Madrais can be found in the literature in the virtual world, as well as a figure found in the area Cipari (People of Islam) when asked about the teachings Madrais no human values and nationalities deliberately covered by figures who were interviewed, on October 31, 2012. that belief, evident from the character's faces when the gambling explained Madrais, but when asked about the disposal Madrais he did not know it at all, whereas Madrais in waste during depalan years.
} 
Madrais teachings that still exist today; it was not a label or a naming that came from within, but rather a label deliberately given from the outside. The label given by outsiders made the spiritual teachings increasingly marginalized. The contradiction of marginalization to the Sunda Wiwitan Community involved the elimination of identity as a tribe that was upheld by the Indonesian national law itself.

The 1945 Constitution has embodied the spiritual Madrais with the constitutional rights against believers against God Almighty. ${ }^{22}$ Along the way, the development of Indonesia's positive legal history says otherwise. The stigma of the original spiritual teachings of Indonesia includes Madrais teachings as animism, godless, kafir, so it needs to be nurtured and supervised. National legal discrimination began to be felt on August 1, 1954, until 2012, now that the original spiritual teachings of Indonesia do not gain a living space in their homeland. ${ }^{23}$ As a result of discrimination by national law, Madrais followers find difficulties in obtaining their constitutional rights, namely:

1. The state does not recognize the traditional marriage of Sunda Wiwitan Culture as a legal marriage;

2. Excerpt of the Marriage Deed does not include the father's name of a child who has been born;

3. Treatment of teachers in public schools of children from the KSW;

4. Identification card (ID card/KTP), denoted by a sign (-) for the religious column.

In line with the view of Mansour Fakih that stated: ${ }^{24}$ The social system and culture that we are establishing is a system that can systematically undermine the essence of our humanity. Also towards the words of Mansour Fakih, if it is interpreted essentially, the words contain an understanding in which the social and cultural system built in the present time and it systematically undermines the true humanity of the Indonesian nation. The author deliberately quoted Mansour Fakih because the statement was very factual with the current state of Sunda Wiwitan Community and the indigenous communities of the archipelago in other areas. Indonesian national law itself has systematically undermined the essence of Madraic teachings on the values of nationality and humanity. There has long been a gulf between national law and indigenous community law from various

\footnotetext{
${ }^{22}$ First Precept of the five existing precepts have given space, the teachings Madrais, as a category of cult. Konstusional more clearly to the right can be seen in the 1945 Constitution that has undergone a change.

${ }^{23}$ It is said pad Work Shop on Sipol and Political Rights in the House Tri Panca Tunggal Cigugur on November 6, 2012 as a series of events Seren Taun.

24 Mansour Fakih, Bebas Dari Neoliberalisme (translate: Free Of Neoliberalism), Yogyakarta: Insist Press, (2005), p. 1.
} 
quarters, including by Indonesian academicians and legal practitioners in discussing indigenous Indonesian spiritual values. As a reflection, wishing to open space in search of long-worn values, which in essence has given a tremendous contribution in shaping the values of nationality in Indonesia.

The symptoms arose in 2012 showed that much violence appeared in the name of religion, resulting in the protection of minority rights as a sweetener of the Indonesian national law. Also, it made the community lose the identity as a citizen, for the child, they lost the rights to get a better education. Various literature reviewing Customary Law had not been found on the protection of the basic rights of indigenous peoples by the state. The various customary law literature generally discussed only the uniqueness of the law of a particular indigenous community, and there was no writing that solved the process of marriages, it was always done customarily, and to be recognized by the state of Indonesia.

\section{Saving Customary Marriages KSW Pulls out the Laws Regulation and Pulls up Its Implementation in Indonesia}

Human beings need a clear identity of marriage. It is done by Gumirat Barna Alam and Susilawati. Ideally, the marriage is registered by the Civil Registry Office (Kantor Catatan Sipil/KCS). But in the practice of the implementation, there is a policy to be followed. The case lawsuit of the couple Gumirat Barna Alam and Susilawati which both are the believers of Sunda Wiwitan beliefs against East Jakarta KCS who refused to record the marriage of the couple. ${ }^{25} \mathrm{KCS}$ refers to the Ministry of Home Affairs Letter No. 474.2 / 309 / PUOD dated October 19, 1995, to the Governor of Jakarta, which stated that the registration of marriages for the seeker of belief in God would first be delayed to be processed. ${ }^{26}$

According to the judiciary, it is important that the law should conduct a marriage. However, there are different interpretations of Law No. 1 of 1974 on Marriage. Article 2 paragraph (1), "Marriage is lawful if done according to the law of their respective religion and belief." Article 2 paragraph (2), "Every marriage shall be recorded according to the prevailing laws and regulations." The KCS and the Department of Religious Affairs interpret the word "belief" by the sound of Article 2 Paragraph (1), as a belief in the religion, meaning "religion" and not others. There are also those who understand their 'belief' according to article 2 verse (1), different from religion and need provision. The Supreme Court once issued a jurisprudence certifying the marriage of interfaith beliefs. MA jurisprudence can already be

\footnotetext{
${ }^{25}$ News Paper Indonesia, Compass Saturday 10 May 1996.

${ }^{26}$ Gumirat Barna married Susilawati Nature and not by religion, but based on traditional Sundanese
} 
used as the legal basis for the marriage ceremony. So, no longer need the MA decision, even if MA wants to give it. So the government needs to review and revoke the regulations under the laws that prevent citizens from registering their marriages. Because the Act No. 1/1974 guarantees the validity of marriages conducted according to religion and belief.

Article 29 Paragraph (1) of the 1945 Constitution declared that "The state is based on the Almighty God," while in article 29 paragraph (2) declared that "The State guarantees the freedom of every citizen to embrace his or her religion and to worship according to his religion and belief." So, citizens who embrace any religion universally acknowledged by humankind, they must receive administrative services from the state. ${ }^{27}$ It cannot be justified that KCS refused the recording of marriage based on custom according to one's belief. If the refusal is said to be based on a lower regulation of the law, then under the general provisions of the law it is null and void. $^{28}$ In this regard, the government should review and revoke regulations that are contrary to the 1945 Constitution and the law. Then the Supreme Court needs to conduct a judicial review. ${ }^{29}$

The recording is only to prove administratively that a legal event has occurred, in this case, is marriage. It should be seen solely from the point of state administration. The state must distinguish marriage recording as a legal event with the validity of marriage according to religion and belief. Therefore, the KCS as the state apparatus is obliged to record the legal event in the form of a marriage requesting to be registered. It is the responsibility of the bride and groom to validate marriage according to their respective faiths and beliefs. ${ }^{30}$ Recording of marriage which is mostly triggered by the rejection of marriage recording for adherents of belief or custom, by consideration of Article 2 paragraph (1) of Law No. 1/1974. ${ }^{31}$

27 Look et Notonegoro, Pancasila Sebagai Falsafah Dasar Negara/Pancasila Basic Philosophy of the State (Collection of the Three Principles of the Problem of Pancasila), Jakarta: Bina Aksara, (1988), p. 27.

28 Article 24A paragraph (1) of the 1945 Constitution, "the Supreme Court authority to examine the legislation under the law of the law"

${ }^{29}$ judicial review carried out by the Supreme Court to test the law reserved under law and cancel the legislation if it is contrary to the law.

${ }^{30}$ Minister of Justice: According to the law, Customary marriages can be listed Jakarta, Kompas Oetojo Oesman Justice Minister admits that the interpretation of the Act (Act) No. 1 of 1974 on Marriage is still diverse. Nevertheless, the customary marriage that couples seeker can duly listed in KCS (Civil Registry).

${ }^{31}$ The sound of article referred to is, "Marriage is legal, if done according to the laws of each religion and belief it." Speaking of article 2 of the Law on Marriage, indeed talk about the differences of interpretation as to whether the word "religion" and "belief" that there in that chapter is one unit. If it is unity, then if someone does marriage only based on religious or 
However, there is also another interpretation stating that religion and belief are two different and separated entities so that for those who conduct the marriage according to the belief or the tradition only, then KCS should not refuse to record the marriage of the respecting couple. In the author's opinion, it is stated that the respective interpretation is the one that could be acceptable. The function of KCS is only to record the law events that happen concerning the birth, marriage, and the death of a person. The person entitled to determine the validity of a marriage, religion or state in this case the marriage is the registry officer. Article 2 paragraph (1) of Law No. 1/1974 gives the authority of the legitimacy of the marriage, to the religion and beliefs of the people concerned. This article explicitly says that "marriage is lawful if done according to its religious law and belief." It is true that Article 2 Paragraph (2) states that "each marriage is recorded according to the prevailing law," but the marriage does not or has not yet registered the effect on the validity of the related marriage. Jurisprudence of The Supreme Court in Reg No 2147 / Pid / 1988 dated July 22, 1991 which among others states, "Marriage which has been held according to the law and its belief is valid according to the provisions of Article 2 paragraph 1 of Law No. 1 in 1974 (Marriage Law), and the problem is not registered a legal marriage in accordance with the provisions of article 2 (2) of Law No. 1 of 1974, does not make the marriage illegitimate".

The establishment of the Supreme Court was then reaffirmed by the jurisprudence of MA Reg No 1073 K / Pid / 1994 dated February 4, 1995. Various interpretations, the most disadvantaged party is of course women. In unrecorded marriages, a man can casually leave the wife unencumbered with any responsibility, either to the wife or children born of a related marriage. Tragically, this is still much happening in our society not only because of their lack of legal awareness but also because of the unaffordable administrative costs due to their poverty. For those who still live in the interior or the mountains as well, they cannot go to the office of the marriage registry officials, including the filing of istbat to the Religious Courts which are generally located in the district. In that connection, marriage recording efforts for those whose marriage has not been recorded should be facilitated. Is it possible that the records (for those who have been married according to religion) are done for example the clemency which is done on the birth certificate in Jakarta some time ago, or like the Prona program for the land certificate? It is ironic if a marriage that is a form of obedience to the Creator and the Prophet in fact occurs and fulfills the provisions of religious law and

customary course -not based on religion recognized by the state then the marriage was not valid, as adopted by KCS (Civil Registry) during this time. 
belief, but it still requires the decision of others to be registered or declared legitimate. ${ }^{32}$

In our very diverse society, the application of regulation must consider the law and a sense of living justice and the socio-economic conditions of the people concerned. And more importantly, to apply the law by upholding the principles of human rights including women's rights as contained in the Convention on the Elimination of Discrimination Against Women which has been ratified by Law No. 7 of 1984. ${ }^{33}$ The Supreme Court granted the marriage registration application of Parlin and Endang Sri Ambarin, Sapta Darma. Besides the two were permitted to hold marriage in the presence of Civil Registry Extraordinary Employees, the Supreme Court also ordered KCS to record their marriage. The decision of the Supreme Court is, of course, relieved the hearts of Parlin and Endang Sri Ambarin. Also, the request to get married in KCS previously had been rejected by the Religion Court in Pati (Central Java). ${ }^{34}$

The marriage of the couple had been done in July 1988, but it was considered illegitimate because it was rejected by the registry office. Both of them applied to the district court in Pati in 1991 and then it was rejected. They then submitted cassation to the Supreme Court then it was granted by the court. ${ }^{35}$ Although Pri Arlin had had the act of Marriage, but he still felt disappointed because his first child Eko Teguh Pranawa who was born on April 13, 1989, had not achieved the birth Act yet. The child was considered as the illegitimate child. On the other hand, Sigit Raharjo, the second child who was born on December 15, 1996, had already received the Birth Act. ${ }^{36}$ Based on the circular letter of the Central Java Provincial Government on

\footnotetext{
${ }^{32}$ However we must realize that the implications of a regulation would be very different, not only against particular groups of people according to gender, religion, culture, or ethnic origin but also by social class and region in which they live.

33 (Nursyahbani Katjasungkana and Sri Wiyanti, lawyers) Legal Note Nursyahbani K and Sri Wi yes n ti Validity of Marriages, Authority Who? Paper Cigugur 2014.

${ }^{34}$ On the basis of the Supreme Court decision No. 1559 K / Pdt / 1991 dated January 12, 1995 that, then KCS Pati issued a marriage certificate on behalf of Parlin and Endang Sri Ambarin on 1 September 1995.

${ }^{35}$ Said Parlin encountered in his Kompas Randu Hamlet, Village Kutoharjo, Keca- honor Pati City, Friday (9/5). Look Deddy Mulyana dan Jalaluddin Rakhmat, Komunikasi Antarbudaya:Panduan Berkomunikasi dengan Orang-Orang Berbeda Budaya, Bandung: Remaja Rosdakarya, (2016), p. 25.

${ }^{36}$ It is said, the seeker of trust concerned has also applying to get married in front of KCS officers Pati, but until Friday (9/5) it is not known for sure whether their application is rejected or accepted. Parties Registrar PN starch which has not been willing to explain in detail about the case file members of Sapta Darma marriage petition in question. "We must open the archive first, and had to ask permission of the local Court Mr. Chairman. Pri archive coincidentally Arlin and Endang Sri Ambarin we found, "said the source K ompas in PNPati handing the archives.
} 
January 3, 1996 No. 447/22945, addressed to all mayors/regencies, stating that marriage of the believer to the Supreme God cannot be registered in the registry office even the determination of the District Court confirmed it. ${ }^{37}$ As the effect from the state that did not give space for KSW, in practice, there was a lot of political effort done by KSW to get the identity from the state.

\section{The Efforts to Fool the State In The Rescue of Formal Education in the Midst of Liars the Right of Constitutionality}

There is a lot of confusion about the existence of KSW's children in formal education. Also, the researcher has to collect data from the real and direct sources to find out some things related to formal education. It is done to get the clarification of the spreading information out there. One of the KSW community says that:

"There is a way for us to get a formal education well, that is by entering on a religion recognized by the state, such as Protestant or Catholic religion, then we will be given religious matters relating to that religion." ${ }^{38}$

The same thing is also said by Sutarman (27 years) "to get my religious values, I have to convert to the Protestant religion." It is done because, I will not get a religious value or in other words, I will not be able to join the class. However, Sukanda (24 years) stated that:

"I have achievements in the table tennis sports and become a champion of the Kabupaten Elementary School category. Usually, the school provides relief to the students who excel to choose the target of junior high school, and it will be a guarantee to enter the next degree of school. But the school did not want to give recommendations on me to struggle with my achievements".

It is the reason that makes Sukanda lazy to continue his study. Moreover, he chooses more to help his parents at home. Besides, the school also rejected him because of the inability to show his birth act from the state. Birth Act is the final and the absolute requirement for those who want to continue their study. Also, religion is one of the factors and the reasons why the kids would be able to continue their study. The inexistence of the birth act or having no religion, it will cause another difficulty for them such as the teacher will be able to give a score, and they could not go to the higher

\footnotetext{
37 The consideration, it is not in accordance with applicable law. The circular was also mentioned, with political considerations, legal and other societal aspects, the Minister of the Interior letter dated July 25, 1990 No. 477/2535/PUOD concerning Marriage Registration for the seeker of Trust in God Almighty, previously delayed its implementation. (Soup) MA grant application Couple "Hanging Kebo"

${ }^{38}$ Interview with KSW warge Suhari from Cirebon on November 5, 2012.
} 
classes because the religion score has no score. By joining Protestant or Katolik itself still faces difficulty because most of the teachers are Muslim so that the teachers are rarely giving a high score which should be based on the ability that the students have.

On the other hand, for the students who are Moslem will be able to get a high score. It was proved during the Primary School or Junior High School. The condition of the education gets an effect from the law state which has circumcised the constitutional rights of the KSW. That is why in the researcher's point of view, the state has considered the children of KSW as the children who do not deserve a proper education just like the orphans.

In line with that, while we are talking about the orphans, we are going to talk about the children who do not have father or mother. However, for the matter of writing, the researcher borrows the term said by M. Dawam Raharjo during the National Symposium in Cigugur on September 23, 2012. M. Dawam Raharjo said that:

"Islam means the well-being of the inner and outer in which the society is free from deficiencies and poverty ..." if we do not pay attention to the oppressed people we are religious. Many, once orphaned Indonesians in need of protection, so orphans are not children who have no parents, including those who are treated unfairly enter in it. ${ }^{39}$

The real evidence could be got from the Sunda Wiwitan Community, where they are pushed to follow the regulation of the country without previously considering the values of the local wisdom of the Sunda Wiwitan itself. For example, it was found that in the statement on the Birth Act that stated: "has been born a child from a woman named...". ${ }^{40}$ By reading the Birth Act statement, the researcher has a cynical point of view about that. The cynical is related to the admission of the child as the evidence from the parents of the father. This is across to the international convention about the protection of women and children. If we go further to the positive law side in Indonesia, it is what is written in the Birth Act that contains a bias interpretation. If the statement is stating that "has been born a child from a woman named.." it has a meaning that the child was born with no explanation which the father is. This is, of course, a contrast to the basic value of the Sundanese community itself that states "Bapa tangkal darajat

\footnotetext{
${ }^{39}$ More see M. Dawam Rahardjo, Energy and the Environment Food Perspectives Islam, Cigugur 23 September 2012. Look et, Sugianto,"Hak Warga Negara Dalam Memperoleh Pendidikan/ Rights of Citizens in Obtaining Education", Objective and Accurate Sources of Islamic Studies, 4 (1), (2011), p. 54.

40 This turned out to refer to Law Number 23 Year 2006 concerning Population Administration and Kuningan Regent Decree No.474/KPTS.146-BKKBCS/2008 dated 10 April 2008.
} 
Ibu pelindung kalbu/father tara datjat mother protector heart." The existence of a silly quotation from Sunda Wiwitan which is expressed by Kento, for example, is as follows:

Although I am a Sundanese Wiwitan, I give the children freedom to get religion according to the beliefs of the children. We do not curb the children to follow us because we prefer the democratic values in the family, but I say never to break the rules of religion with a tradition of the Sundanese. ${ }^{41}$

As been said by Mr. Kento himself, there are a lot of values that could be got related to beliefs which are mentioned as follows:

a. Adherents of Sunda Wiwitan give freedom to their children to choose any religion;

b. Freedom is based on the values of the democratic election of belief;

c. The community agrees to respect every believer of a certain belief.

The values above are quite different if they are compared to the teachings existed in Islam which states that if the person from Islam has decided to believe in other religion, then the person is said to be Murtad, and also in Catholic, Protestant, Hindu, Buddha which have the same religion value with different term to be used. The community of Sunda Wiwitan has no strict rule for its follower to choose the religion that the followers believe. Then, the researcher says that it is one thing that should be appreciated in the life of the nation and for the freedom to believe in certain religion, which those two aspects do not exist in every religion that is recognized by the country. Some other citizens agree with Mr. Kento statement that mainly the Sunda Wiwitan community has no strict rule for its followers to choose any religion based on their belief but the other hand, the followers are mentioned not to forget the local values as a Sundanese. It is in line with the statement that comes from Prince Djatikusumah that stated: "we may have a different belief but we have to be one as a nation." The statement is warming the heart which is related to the openness of the Sunda Wiwitan Community in keeping its tradition. Thus, the tradition of Sunda Wiwitan does not belong to a certain small community, but it belongs to all Sundanese in general.

The warming statements sometimes burden the community of Sunda Wiwitan which the real meaning should be meant as the openness of Sunda Wiwitan Community that is then legitimized by the country as a marginalized community. Back to the statement in the Birth Act, which in practice, many followers of Sunda Wiwitan Community has no equality in the chance of pursuing the education. Then, for the researcher, it may be a

${ }^{41}$ Interview with Kento pack which is a retired civil servant in Kuningan, the interview conducted at his residence which is in Cipager Wetan Village Cigugur Cigugur District of Kuningan District in September 2012. 
possibility of redirection for the community of Sunda Wiwitan regarding the religion that is admitted by the legal religion from the country as the effort in saving their lives. It also can be described in Madrais Ali Basa statement that says to the followers "protect yourself under the white fir trees." The meaning from the statement is giving the freedom for Sunda Wiwitan Community as the effort in saving their lives. ${ }^{42}$

Until the present time, the position of the children that come from the traditional marriage of Sunda Wiwitan cannot have the constitutional rights as a whole. While the children are the child of the nation that has the same rights in education to pursue a proper education or even get a proper job. The constitution is the only constitution because it shows its inability to protecting the nation. ${ }^{43}$ The article $28 \mathrm{~B}$ of the 1945 Constitution states in verse one (1) that everyone has the rights to form a family and continue to reproduce through legal marriage. If the article is viewed further, then it will have meaning that everyone has the freedom to conduct a legal marriage. Thus, it raises a question whether the marriage which is done traditionally in Sunda Wiwitan tradition is legal in the area of the law. The question then needs to be answered by analyzing the intention and the meaning of the article itself.

By stating that the Article 28B in verse (2) that say "every child has the rights to continue his/her life, grow and also has the right to be protected from violation and discrimination." The researcher reviews the statement in the Birth Act further that for the community of Sunda Wiwitan, by having a relationship with the mother is consciously being discriminative, besides the school is sometimes being discriminative for the kids that come from the community of Sunda Wiwitan so that the kids feel uncomfortable to continue their education. However, according to the researcher's point of view, it becomes the lost for the Indonesian law, and it goes the other way for the Sunda Wiwitan Community.

\section{Formal Religious Identity Inclusion Efforts For Getting a Job and Retain Jobs In Order of the Fulfillment of Family Economics}

In addition to conducting a political movement to save the marriage and education for KSW, they also do the political movement to get a job and keep a job as a shape to meet the needs of families. It is said to get a job

\footnotetext{
42 The phrase 'take cover under cermara white' in their own interpretation of society Cigugur save themselves from the threat danger, Ms. Uum tongue in Cipager Wetan in October 2012. But for the writer to see the fact of religious symbol synonymous with the big fir Christmas held every 25 th of December.

${ }^{43}$ In this paper I use the term nation, as many followers Sunda Wiwitan are indifferent to the State, but prefer to use the name of the nation. Therefore, the nation itself pemaknaannya I mentioned in the original writing.
} 
because there are several reasons that it faces. At the time of going to work, when he saw the column of religion (-), it automatically will not be accepted, as was done by Tarmadi (35 years). Tarmadi said "when they have a column (-) on the ID card, I had difficulty in getting a job. When after switching on the Catholic religion on identity cards, I can be received well at work. Though I rarely to church to pray, religious premises other words I use as an effort to can job ". ${ }^{44}$ It's, proving that formal religion is used as a means or tool to get the job. So that the one that has been done by the other member of Sunda Wiwitan Community.

While formal religion is used to retain the work done by Mr. Eli working in Cirebon as a civil servant, he said. "To be appointed as a civil servant in the 1990s only those whose religion recognized by the state. Then my friends suggested that I embraced, even if only for civil servants. Then I chose the Catholic religion on the ID card, not long after I was appointed as civil servants. Who was working as an Honoree in the Government of Cirebon. ${ }^{45}$ Various methods or politics run by KSW as a form of resistance to perceived legal state never do justice to the citizens.

It is by the one that has been told by a senior official and Mr. Eli simply examples. Even within their practices more KSW people who do that. As the exposure is also conveyed by the Community Sapto Darmo in Cigugur, "for the ID card, we have to follow the religions officially recognized by the government to obtain the same rights as other citizens in Indonesia. ${ }^{146}$ Looking at the efforts made by indigenous communities' stretcher is clear, how the state has committed acts that are considered as castration. Then the communities of different resistance make an effort to get a constitutional right. The inclusion of formal religion in an attempt to save themselves from the confines of work and the demands of the economy, making KSW doing so despite having a conflict with his conscience.

In 2000, the provisions on human rights and the rights of citizens in 1945 , experienced a very fundamental change. The material originally only contained 7 grains provisions also do not fully be referred to as a guarantee of human rights, now has grown significantly, so that the formulation to be complete and makes 1945 is one of the basic law of a complete load of human rights protection. However, it is necessary to reflect on the 1945 Constitution, the rights of indigenous communities in the Constitution of 1945. So, it will determine whether the country has made protection of human rights to see the diversity of cultures and customs that exist in the

\footnotetext{
${ }^{44}$ Interview Tarmadi Park Paseban Tri Panca Tunggal, Cigugur, Brass, November 7, 2012.

${ }^{45}$ Interview with Mr. Eli in California on vacation pas week in October 2012.

${ }^{46}$ Events Social Rights and Political Rights in the Work Shop, which was held on October 4, 2012 at the House Paseban Tri Panca Tunggal Cigugur.
} 
archipelago. With the passing of the Second Amendment of the 1945 Constitution in 2000, and if the material is combined with a variety of provisions in the law relating to human rights, then the whole legal norms concerning human rights can be grouped into four groups containing 37 grains provisions.

In the 1945-G Article 28 Paragraph (2) "Set each person has the right to freedom from torture or degrading treatment of human dignity and the right to obtain political asylum in another country". Real evidence found in the KSW and Indigenous Communities, it turns out the state law Indonesia has done restraint on marriage customary marriages. Finally, the country has been degrading the dignity of KSW and indigenous communities in the archipelago. Also, the statement stating that ".... and the right to obtain political asylum in another country". Sentence fragment such, seems pretty it would boomerang on the country. Therefore, political asylum can be used by persons who are not responsible for destroying the nation.

\section{Conclusion}

In general, identity politics can be seen as the end of the long process of the uncertainty of the identity. The identity politics is felt like the hardness of the identity because of the act of worrying towards the marginalization done by the majority. The identity politics is formed in the process of knitting the constitutionality of rights for the minority. The Identity politics of the Sunda Wiwitan Community is cut and allowed only to scream the broken hearts and felt like the victims in the era of the constitutional era. The discussion about the rescue of the marriage and the education has saved the KSW to get the identity as the citizen to fulfill the needs of the family economy. Although deep down inside. There still a feeling about the discrimination that is done purposively by the country. As the constitutional country, Indonesia should be able to provide the admission of the minority rights. In line with that, Indonesia was formed based on the constitution and not based on the existence of the dynasty.

\section{Bibliography}

\section{A. Books}

Dahlan Thaib et all. (2004). Teori Hukum dan Konstitusi/Theory and Law of the Constitution, Jakarta: Raja Grafindo Persada.

Deddy Mulyana dan Jalaluddin Rakhmat. (2016). Komunikasi Antarbudaya:Panduan Berkomunikasi dengan Orang-Orang Berbeda Budaya. Bandung: Remaja Rosdakarya.

Djokosutono. (1982), Hukum Tata Negara/Constitutional Law, lectures compiled by Harun Alrasid in 1959. Jakarta: Ghalia Indonesia. 
Fakih, Mansour. (2005). Bebas Dari Neoliberalisme/Free Of Neoliberalism, New Edition. Yogyakarta: Insist Press.

Kusnardi and Harmaily Ibrahim. (2000). Hukum Tata Negara Indonesia/Indonesia Constitutional Law. Jakarta: Faculty of Law. The University of Indonesia.

Maarif, Ahmad Syafei. (2012). Politik Identitas dan Masa Depan Pluralisme Kita/Identity Politics and the Future of Pluralism We, the Foundation Ages Democracy. Jakarta

Maarif, Ahmad Syafii. (2009). Islam in the Indonesian Framework of Keindonesiaan and Kemanusiaan: A History Reflection. Bandung and Jakarta: Mizan-Maarif Institute.

Notonegoro. (1988). Pancasila Basic Philosophy of the State (Collection of the Three Principles of the Problem of Pancasila). Jakarta: Bina Aksara.

Rahardjo, M. Dawam. (2012), Energy and the Environment Food Perspectives Islam, Cigugur.

Strong, C.F. (2004). The Constitutions of Modern Politics The Study of the History and Establishment of the Constitutions of the World, SPA Teamwork. Bandung: Nuansa and Nusamedia.

Tutik, Titik Triwulan. (2006). Principles of Constitutional Law. Jakarta: Prestasi Indonesia.

\section{B. Journal and Article}

Dewi Kanti, Dynamics of Spiritual Ancestors Preserving Sunda Wiwitan, Cigugur, October 16, (2012).

Kaufffman, LA. "The Anti-Politics of Identity." Socialist Review. 1 (20). (1990).

M. Dawam Rahardjo, Food Perspectives on Energy and Environment Islam, Cigugur 23 September (2012).

Mahmudi, Ahmad. Knowledge No Ivory Tower: Studies in Research Should Favor And N Studies The Impartial, Cigugur October 22, 2012, in the National Symposium event.

National Commission for Women, Work Shop on Sipol and Political Rights in the House Tri Panca Tunggal Cigugur on November 6, 2012, as a series of events Seren Taun. Attended by Indigenous Peoples from various regions, National Commission for Women, Ministry of Justice and Human Rights, Society, as well as academics in Indonesia.

News Paper Indonesia, Compass Saturday 10 May 1996.

Nursyahbani Katjasungkana and Sri Wiyanti, lawyers, Legal Note Nursyahbani $K$ and Sri Wi yes $n$ ti Validity of Marriages, Authority Who? Paper Cigugur 2014. 
Slamet DKK. "Pemanfaata Ruang Telaga Pada Tradisi Sedekah Bumi Desa Cerme Kidul Kecamatan Cerme Kabupaten Gresik". RUAS Journal. 13 (1). (2015).

Sugianto. "Hak Warga Negara Dalam Memperoleh Pendidikan/ Rights of Citizens in Obtaining Education, Objektive and Accurate." Sources of Islamic Studies. 4 (1). (2011).

\section{Legislations}

Republic of Indonesia Law No. 1 on 1974 of Marriage.

Republic of Indonesia Law No. 12 on 2006 of Citizenship

Republic of Indonesia Law No. 23 onr 2006 of Population Administration and Kuningan Regent Decree No. 474 / KPTS.146-BKKBCS / 2008 dated 10 April 2008.

Minister of the Interior dated July 25, 1990 No. 477/2535 / PUOD concerning Marriage Registration for the seeker of Trust in God Almighty, previously delayed its implementation. (Soup) MA grant application Couple "Hanging Kebo."

\section{Interview and Discussion}

Barna Gumirat Nature, Oki, Dewi Kanti S. Sarip, and Ali Ramadhoni, In a casual chat in Lima Marapat House lawn, on Sunday, October 14, 2012.

Darja, Interview Park Cigugur Paseban Tri Panca Tunggal, Brass, November 7, 2012. Cigugur, Brass, November 3, 2012.

Dewi Kanti and Oki Satrio, at the Discussion About Community Sunda Wiwitan Cigugur in Paseban dated October 22, 2012.

Eli, Interview in California on vacation pas week in October 2012.

Kento (Citizens Cigugur), Arga (Citizens Cigugur), in October 2012, and Darja (Citizens Sidawangi-Source-Cirebon) in January 2011.

Sahari who was a Wiwitan Sunda derived from Kanekes (Pandeglang Banten), and Sahari show ID cards on the author to prove, in junior high school Trimulya Cigugur, November 5, 2012.

SMA Mardi Waluya Cibinong, O constellations in pemiihan King and Queen at Art Studio Cigugur, November 10, 2012.

Sudiono (Ono), an interview which is a citizen Paleben this interview was done on his home, Cigugur, Brass, October 29, 2012.

Suhari, interview residents KSW from Cirebon on November 5, 2012.

Tarmadi, interview, Park Paseban Tri Panca Tunggal, Cigugur, Brass, November 7, 2012. 